\title{
Evaluation of Brazil's public health surveillance system within the context of the International Health Regulations (2005)
}

\author{
Maria Glória Teixeira, ${ }^{1}$ Maria C. N. Costa, ${ }^{1}$ Luís P. F. Souza, ${ }^{1}$ \\ Estela M. R. Nascimento, ${ }^{2}$ Maurício L. Barreto, ${ }^{1}$ Neusa Barbosa, ${ }^{1}$ \\ and Eduardo Hage Carmo ${ }^{1}$
}

Suggested citation

Teixeira MG, Costa MCN, Souza LPF, Nascimento EMR, Barreto ML, Barbosa N, et al. Evaluation of Brazil's public health surveillance system within the context of the International Health Regulations (2005). Rev Panam Salud Publica. 2012;32(1):49-55.

ABSTRACT Objective. To evaluate Brazil's public health surveillance system (HSS), identifying its core capacities, shortcomings, and limitations in dealing with public health emergencies, within the context of the International Health Regulations (IHR 2005).

Methods. In 2008-2009 an evaluative cross-sectional study was conducted using semistructured questionnaires administered to key informants (municipal, state, and national government officials) to assess Brazilian HSS structure (legal framework and resources) and surveillance and response procedures vis-à-vis compliance with the IHR (2005) requirements for management of public health emergencies of national and international concern. Evaluation criteria included the capacity to detect, assess, notify, investigate, intervene, and communicate. Responses were analyzed separately by level of government (municipal health departments, state health departments, and national Ministry of Health).

Results. Overall, at all three levels of government, Brazil's HSS has a well-established legal framework (including the essential technical regulations) and the infrastructure, supplies, materials, and mechanisms required for liaison and coordination. However, there are still some weaknesses at the state level, especially in land border areas and small towns. Professionals in the field need to be more familiar with the IHR 2005 Annex 2 decision tool (designed to increase sensitivity and consistency in the notification process). At the state and municipal level, the capacity to detect, assess, and notify is better than the capacity to investigate, intervene, and communicate. Surveillance activities are conducted 24 hours a day, 7 days a week in $40.7 \%$ of states and $35.5 \%$ of municipalities. There are shortcomings in organizational activities and methods, and in the process of hiring and training personnel.

Conclusions. In general, the core capacities of Brazil's HSS are well established and fulfill most of the requisites listed in the IHR 2005 with respect to both structure and surveillance and response procedures, particularly at the national and state levels.

Key words International Health Regulations; health surveillance system; evaluation; Brazil.

Instituto de Saúde Coletiva da Universidade Federal da Bahia (UFBA), Salvador, Brazil. Send correspondence to: Maria Glória Teixeira, magloria@ufba.br

2 Secretaria de Saúde do Estado da Bahia (SESAB), Salvador, Brazil.
Changes in the global health situation related to the reemergence of infectious diseases and exposures to new and potential hazards highlighted the frailty of both the International Health Regulations (IHR) of 1969 (1) and global surveillance mechanisms. Therefore, in 2005, a revised edition of the IHR (2) established a new 
set of regulations for compliance with the requirements for dealing with new health issues and risks considered of international interest (3). This approach broke with the tradition of focusing on internationally notifiable diseases and allowed for the implementation of a more effective surveillance system at a global level (4).

To ensure that the requirements of the IHR 2005 are met, each country is required to adopt initiatives designed to improve technical capacity and overcome political obstacles (5). One of the requirements of the revised IHR is evaluation of the national health surveillance system (HSS) to identify legal, technical, and political limitations and to propose measures to increase capacity in detection, communication, and response to public health emergencies (PHE) of national and international concern (6).

Meeting these requirements in a country the size of Brazil is extremely complex. Brazil is a federal republic that comprises 26 states plus a Federal District and 5564 municipalities. The sub-system for surveillance and control of diseases (the HSS) is essentially maintained and managed by all three levels of government (national, state, and municipal) (7). The HSS is an integrated part of Brazil's national Unified Health System (Sistema Único de Saúde, SUS) coordinated by the Ministry of Health and implemented in all states and municipalities according to Law 8080/90, known as the Organic Health Law (Lei Orgânica da Saúde, LOS) (7-10). The HSS includes the Ministry of Health $(\mathrm{MoH})$ Center for Strategic Information in Health Surveillance (Centro de Informações Estratégicas em Vigilância em Saúde, CIEVS), and a national state-based network of similar centers (CIEVS Network) (11) coordinated by the $\mathrm{MoH}$ and implemented by state and municipal departments of health. The CIEVS Network was established to detect, monitor, and manage PHE.

The objective of the current study was to evaluate the current status of Brazil's HSS, identifying its core capacities, shortcomings, and limitations with regard to dealing with PHE, within the context of the International Health Regulations (IHR 2005).

\section{MATERIALS AND METHODS}

In 2008-2009, using 2007 as the base year, an evaluative cross-sectional study was conducted to assess the system's structure and surveillance and response procedures vis-à-vis compliance with IHR 2005 regulations for management of potential and actual PHE (communicable and non-communicable diseases, and environmental disasters). Data were collected at all three levels of government: national (Ministry of Health); state (health departments for all 26 states, plus the Federal District); and municipal (a sample of 76 out of 5564 municipal health departments). Out of the 76 municipalities in the sample, 46 were selected based on specific inclusion criteria (being a state capital city; having an international port or airport; being situated on a land border between Brazil and another country; and/or being a tourist attraction) and 30 were selected randomly from the remaining municipalities (those that did not meet any of the above-mentioned criteria). The sample was then stratified by region; population size $(<20000,20001-50000$, 50 001-100 000, 100 001-500 000, and > 500000 inhabitants); and health conditions (good, intermediate, or poor) (12).

A semi-structured questionnaire was constructed for data collection from each of the three levels of government based on the definitions contained in Annex 1A of the IHR 2005 ("Core capacity requirements for surveillance and response"). All questionnaire responses were dichotomous ("yes" / "no") except for the overall assessment of the HSS, which was ranked from 0 to 10 . The survey instrument was tested for adequacy in a pilot study and adjusted and fine-tuned accordingly. The questionnaire and study methodology have been used for HSS assessments by all South American countries and some countries from other subregions of the Americas. The questions were designed to collect data on HSS structure (legal framework and physical, human, and financial resources) and surveillance and response procedures (notification, information sources and flows, and data processing and analysis; procedures standardization; laboratory support; social communication; and capacity for coordination and response) (13). Degreed professionals with experience in public health were trained to administer the questionnaire, which was given to high-ranking HSS managers (directors, coordinators, and program heads) at any of the three government levels who were considered key informants. Various pub- lications (e.g., legislation, bulletins, work schedules, and publications) were requested to document the responses to some of the questions. Data on budgets (annual averages for 2006-2008) were obtained from Brazil's information system on public health budgets (Sistema de Informações sobre Orçamentos Públicos em Saúde, SIOPS) (14). The evaluation also included data from January 2007 to December 2010 on the creation and implementation of the CIEVS, the training of specialists in field epidemiology, and new HSS ordinances, obtained from official documents of the national-level HSS (the National Health Surveillance Secretariat, NHSS) at the MoH.

The questionnaire responses were consolidated and analyzed (\% per $n$ ) for the state health departments, the municipal health departments, and the national system as a whole. Means and standard deviations were calculated for the overall assessments of the HHS' capacity to detect, evaluate, report, investigate, intervene, and communicate events related to potential and actual PHE.

\section{RESULTS}

Overall, the HSS has the essential technical regulations in place, along with the infrastructure, supplies, materials, and mechanisms required for liaison and $\mathrm{CO}^{-}$ ordination. However, there are still some weaknesses in the state-level system, especially in border areas and small towns.

Aspects of the HSS deemed in need of improvement at the national level were 1) data analysis ability, 2) establishment of a response plan for laboratories, and 3) training. Crisis communication, communication with health care services, and infrastructure were also mentioned by the professional staff as requiring improvement. At the two other levels of the system (state and municipal), the issues most frequently reported as needing improvement were 1) integration between health services and the development of protocols and plans for dealing with emergencies, 2) the establishment of health committees and institutional development for the rapid response teams, and 3) hiring and training personnel.

The percentage of questions left blank by respondents from state and municipal health departments was very low (about 1.3\%). No questions were left blank by respondents from the national level of the system (the NHSS). 


\section{Structure: legal framework and financial, human, and physical resources}

To meet the requisites of the IHR 2005, Brazil revised and adapted various components of the NHSS legal framework, including the definition of a PHE. Almost all (96.0\%) of Brazil's states (including the Federal District) and $90.0 \%$ of its municipalities follow the statutory law, technical standards, and procedures of the NHSS (Table 1), which offers technical collaboration and support as needed. In the $\mathrm{MoH}$ annual budget allocation for disease surveillance and prevention during 2007-2009, the annual average investment was US\$1.3 billion (or an annual per capita investment of US\$6.8). All states and almost all municipalities (all but $4.3 \%$ ) have a budget earmarked for health surveillance.

At the national level, Brazil has an HSS team fully dedicated to detecting and evaluating potential and actual PHE, supported by a "situation room" located at the national-level CIEVS at the $\mathrm{MoH}$ (the formal IHR focal point) that includes a modern computing system and communication devices with dedicated (permanent) connections to state and municipal health services. The CIEVS interdisciplinary rapid response team works around the clock (24 hours a day, 7 days a week). As of late 2010, the nationwide CIEVS Network consisted of 50 technical and operational units responsible for monitoring, managing, triggering, and coordinating rapid response actions related to PHE.

\section{Surveillance and response procedures}

Surveillance: capacity to detect, evaluate, and notify. Actions concerning PHE surveillance and response are coordinated by the national-level CIEVS. The CIEVS interdisciplinary rapid response team relies on formal and informal sources for immediate notification of diseases with high potential for spreading as well as weekly reports of other relevant public health events, and uses standardized procedures and criteria to detect and verify information on events that could constitute a PHE. In 2007, the CIEVS achieved timely detection of $73.0 \%$ of potential PHE. The inclusion of new, relevant events on the national list of obligatory notification is approved by the NHSS, which maintains a regular flow of communication with the national

TABLE 1. Proportion of state and municipal health departments complying with revised regulations $^{a}$ for public health surveillance structural capacity (legal framework and physical, human, and financial resources), according to key informants, Brazil, 2007-2009

\begin{tabular}{lcc}
\hline \multicolumn{1}{c}{ Capacity } & $\begin{array}{c}\text { Level of government } \\
\text { (\% of positive responses) }\end{array}$ \\
\cline { 2 - 3 } & $\begin{array}{c}\text { State } \\
(n=27)\end{array}$ & $\begin{array}{c}\text { Municipal } \\
(n=76)\end{array}$ \\
\hline Applies national HSS legislation & 96.0 & 90.0 \\
Receives technical cooperation from national level (NHSS $\left.{ }^{b}\right)$ & 100 & 100 \\
Uses procedures described in NHSS guidelines & 100 & 94.5 \\
Has an annual budget for monitoring the HSS and public health emergencies & 100 & 95.7 \\
\hline a World Health Organization revised International Health Regulations (IHR 2005) for national public health surveillance systems \\
(HSS).
\end{tabular}

TABLE 2. Proportion of national, state, and municipal health departments complying with revised regulations ${ }^{a}$ for public health surveillance procedures (capacity to detect, evaluate, and notify), and mean scores (1-10) for overall performance, according to key informants, Brazil, 2007-2009

\begin{tabular}{|c|c|c|c|}
\hline \multirow[b]{2}{*}{ Capacity } & \multicolumn{3}{|c|}{$\begin{array}{c}\text { Level of government } \\
\text { (\% of positive responses) }\end{array}$} \\
\hline & National & $\begin{array}{l}\text { State } \\
(n=27)\end{array}$ & $\begin{array}{l}\text { Municipal } \\
(n=76)\end{array}$ \\
\hline Has team for surveillance activities & 100 & 100 & 98.7 \\
\hline Has team fully trained in the use of the IHR 005 Annex 2 decision toolb & 50.0 & 40.7 & 25.0 \\
\hline Has a physical area set aside for surveillance & 100 & 100 & 92.1 \\
\hline Uses the national list of notifiable diseases & 100 & 100 & 90.8 \\
\hline Uses standardized procedures for data collection & 100 & 100 & 92.0 \\
\hline Conducts surveillance 24 h/day, 7 days/week & 100 & 40.7 & 35.5 \\
\hline $\begin{array}{l}\text { Has outgoing long-distance telephone line dedicated to surveillance } \\
\text { (accessible } 24 \text { h/day, } 7 \text { days/week) }\end{array}$ & 100 & 88.9 & 54.7 \\
\hline \multirow{2}{*}{$\begin{array}{l}\text { Uses informal sources for disease detection } \\
\text { Receives immediate disease notification } \\
\text { (within } 24 \text { hours of detection) }\end{array}$} & 100 & 96.3 & 80.3 \\
\hline & 73.0 & 37.0 & 71.1 \\
\hline $\begin{array}{l}\text { Assessment of overall performance (ability to detect, } \\
\text { evaluate, and report potential and actual public health } \\
\text { emergencies) }\end{array}$ & 7.0 & $\begin{array}{c}6.5 \\
( \pm 1.05)\end{array}$ & $\begin{array}{c}6.5 \\
( \pm 1.91)\end{array}$ \\
\hline
\end{tabular}

a World Health Organization revised International Health Regulations (IHR 2005) for national public health surveillance systems.

b Instrument designed to increase sensitivity and consistency in the notification process.

health authorities in charge of international points of entry with regard to information that may be of interest to the HSS. As the focal point for implementation of the IHR 2005, the CIEVS maintains continuous communication with World Health Organization headquarters in Geneva on all potential and actual international PHE, and participates in the Global Outbreak Alert and Response Network (GOARN) (15).

All of Brazil's states, including the Federal District, and $98.7 \%$ of municipalities have teams focused on implementing HSS surveillance activities. At the state and municipal level, respectively, $40.7 \%$ and $25.0 \%$ of HSS teams are trained to use the IHR 2005 Annex 2 decision tool (designed to increase sensitivity and consistency in the notification process) (1). A specific physical space is available for a health surveillance division in all state health departments and $92.1 \%$ of municipal health departments. The national list of notifiable diseases (those that by law must be reported to public health authorities) is used by all state health departments and $90.8 \%$ of municipal health departments. Standardized data collection procedures are used by $100 \%$ of state health departments and $92.0 \%$ of municipal health departments (Table 2).

In $40.7 \%$ of state health departments and $35.5 \%$ of municipal health departments, public health surveillance activities are ongoing 24 hours a day, 7 days a week. All state health departments and municipal health departments have access to an outgoing long-distance telephone line but only $88.9 \%$ of states and $54.7 \%$ of municipalities have long- 
TABLE 3. Proportion of national, state, and municipal health departments complying with revised regulations ${ }^{a}$ for public health response procedures (capacity to investigate, intervene, and communicate), and mean scores (1-10) for overall performance, according to key informants, Brazil, 2007-2009

\begin{tabular}{|c|c|c|c|c|}
\hline \multirow[b]{2}{*}{ Capacity } & \multirow[b]{2}{*}{ Average } & \multicolumn{3}{|c|}{$\begin{array}{c}\text { Level of government } \\
\text { (\% of positive responses) }\end{array}$} \\
\hline & & National & $\begin{array}{l}\text { State } \\
(n=27)\end{array}$ & $\begin{array}{c}\text { Municipal } \\
(n=76)\end{array}$ \\
\hline Has a rapid response team for $\mathrm{PHE}^{\mathrm{b}}$ & 81.3 & 100 & 78.1 & 65.8 \\
\hline \multicolumn{5}{|l|}{$\begin{array}{l}\text { Has legal mechanisms and features to mobilize rapid } \\
\text { response teams during } \mathrm{PHE}\end{array}$} \\
\hline response teams during PHE & 94.0 & 100 & 96.6 & 85.4 \\
\hline \multicolumn{5}{|l|}{ Has mechanisms for liaising with national- and state-level } \\
\hline system & 61.4 & $-^{c}$ & 100 & 84.1 \\
\hline \multicolumn{5}{|l|}{ Has access to public health reference laboratory for sample } \\
\hline processing & 91.9 & 100 & 100 & 75.8 \\
\hline \multicolumn{5}{|l|}{ Has access to laboratories of universities or other institutes } \\
\hline for sample processing & 92.6 & 100 & 92.1 & 85.7 \\
\hline Has personnel trained in collecting and sending samples & 94.1 & 100 & 95.0 & 87.2 \\
\hline $\begin{array}{l}\text { Has mechanism(s) for urgent dispatch of samples to national } \\
\text { reference laboratories }\end{array}$ & \multicolumn{4}{|c|}{ Has mechanism(s) for urgent dispatch of samples to national } \\
\hline Meets requirements for biosafety procedures & 46.4 & 50.0 & 40.3 & 49.0 \\
\hline Has personnel trained in use of social media & 80.0 & 100 & 77.1 & 62.9 \\
\hline Prepares press releases and circulars & 93.1 & 100 & 94.2 & 85.1 \\
\hline $\begin{array}{l}\text { Assessment of overall performance (ability to investigate, } \\
\text { intervene, and communicate events related to potential } \\
\text { and actual PHE) }\end{array}$ & $\begin{array}{l}\text { Mean, (standard } \\
\text { deviation) }\end{array}$ & $\begin{array}{c}7.0 \\
( \pm 1.3)\end{array}$ & 6.0 & $\begin{array}{c}5.5 \\
( \pm 1.1)\end{array}$ \\
\hline
\end{tabular}

a World Health Organization revised International Health Regulations (IHR 2005) for national public health surveillance systems.

b Public health emergencies.

c Question only submitted to respondents at state and municipal level.

distance lines fully dedicated to surveillance activities (available 24 hours per day, 7 days per week).

The low percentage of positive responses to three questions about HSS surveillance capacity-training personnel in the use of the Annex 2 decision tool; fully dedicated (24/7) surveillance; and immediate notification of events-raised serious concern. Based on the responses, surveillance systems in municipalities located on land borders and those with less than 20000 inhabitants were the weakest, especially with respect to training of technical staff on the use of the Annex 2 decision tool (a criterion for which only $11 \%$ of respondents answered "yes"). In these same two groups of municipalities, only $33 \%$ of respondents said the HSS carried out uninterrupted (24/7) local surveillance. Active case search and weekly collection of disease notifications were the only activities for which $100 \%$ of key informants from municipal health departments provided a positive response. In their assessment of overall HSS performance, the national professional staff gave the system a mean score of 7 (on a scale of 0 to 10) for its capacity to detect, evaluate, and report potential and actual PHE. For the same criteria, state and municipal professionals awarded mean scores of $6.5( \pm 1.05)$ and 6.5 ( \pm 1.91$)$ respectively.

Response: capacity to investigate, intervene, and communicate. To investigate, intervene, and communicate events related to potential and actual PHE, the national-level HSS has mechanisms and resources to 1) mobilize personnel, 2) carry out emergency interventions, and 3) maintain a dedicated connection to the social communication services of the national-level HSS. During emergencies, epidemiological alerts are sent to health care professionals and information is disseminated immediately via the Internet. The CIEVS situation room is designed for responding to major PHE, which includes putting mechanisms in place to establish online communication with the situation room of the Office of the Presidency. The national-level HSS also has communicational channels with strategic national and state institutions within and outside of the health sector, as well as established coordination mechanisms at the international level for the implementation of investigation and control measures.
The majority of state health departments $(78.1 \%)$ and municipal health departments $(65.8 \%)$ have rapid response teams for PHE (Table 3). Resources to dispatch personnel in cases of emergency are available in $96.6 \%$ of state health departments and $85.4 \%$ of municipal health departments. Although few states (17.4\%) and municipalities (12.5\%) have organized a public health committee to respond to emergencies, all states and $84.1 \%$ of municipalities have mechanisms for rapid communication with other levels of government within the public health system. The majority $(77.1 \%)$ of states and $62.9 \%$ of municipalities have personnel trained in social communication, and many $(94.2 \%$ of state health departments and $85.1 \%$ of municipal health departments) prepare their own press releases and circulars.

All states and $75.8 \%$ of municipalities have public health reference laboratories, and the majority of them $(92.1 \%$ and $85.7 \%$, respectively) have a system in place for sending samples for processing in specialized laboratories at universities or research institutes. Most states $(95.0 \%)$ and municipalities $(87.2 \%)$ have personnel trained in collecting and shipping biological samples, as well as mechanisms for sending the samples to national referral laboratories $(85.4 \%$ of states and $91.0 \%$ of municipalities) when necessary. However, few comply with all of the required biosafety procedures (only $40.3 \%$ of states and $49.0 \%$ of municipalities).

As was the case with surveillance capacity, between 2007 and 2009, the performance of the municipalities situated at land borders and those with less than 20000 inhabitants was not high in terms of response capacity, with just $63.0 \%$ and $54.5 \%$ receiving positive responses, respectively. For the system's capacity to investigate, intervene, and communicate events related to potential and actual PHE, technical staff at the national-level HSS gave themselves a mean score of 7 , while those at the state and municipal level gave themselves a mean score of 6.0 $( \pm 1.3)$ and $5.5( \pm 1.1)$ respectively for the same criteria.

\section{DISCUSSION}

The results of this study showed that, in general, the core capacities of the Brazilian HSS have been well established and the system is in compliance 
with most of the IHR 2005 requisites, particularly at the national and state level. These findings are in agreement with previous reports $(15,16)$, indicating that the strategy of decentralizing HSS actions and financial resources from national to state and municipal governments, with defined responsibilities for all three levels of government $(17,18)$, has been successful.

New legal instruments to respond to PHE in accordance with the IHR 2005 have already been promulgated in some countries, such as Argentina (19) and Switzerland (20). In contrast, in Brazil, there is no consensus on how to address the inadequacy of current national laws in meeting the requirements of these regulations. Debate is under way about the appropriateness and terms of new legislation to ensure compliance with IHR 2005. One issue that has evoked much discussion is the risk that this type of legislation may restrict individual rights established in the Brazilian Constitution in situations that require the adoption of specific measures of containment during a PHE, such as quarantine and compulsory isolation (21-23). While the results of this evaluation do not suggest that promulgation of new national surveillance law in Brazil is imperative, consensus has not yet been reached on this issue.

Satisfactory ratings of the HSS' capacity for surveillance and response by key informants may be due in part to the systematic adoption of national technical regulations for surveillance and control of diseases, which may also help create the conditions required for rapid response in the case of unexpected events. Furthermore, Brazil's HSS is based on an integrated structure in which each component communicates with and supports the others, a characteristic that optimizes the use of available resources.

In 2007, the decision tool described in Annex 2 of the IHR 2005 (2) was not yet accessible to many professionals working in public health surveillance in Brazil. Since 2009, however, the HSS has promoted special training to increase capacity in the use of this instrument (24).

Scores given for HSS performance by state and municipal professionals at their respective levels were less favorable than those given by national-level professionals, suggesting that much effort is still required to reach a better standard of surveillance and response in HSS practices at the local level.
Dealing with the problems of reemerging diseases and other health risks is a challenge to any health system. Since 2000, the Brazilian government has adopted several initiatives to increase its capability to respond to these types of events. Of these, the training of specialists in field epidemiology and the creation and implementation of the CIEVS Network deserve particular mention. This network has improved the quality of the HSS, increasing the overall sensitivity of the system in detecting events that may constitute potential PHE, and given the HSS more agility-speeding up information flows and thus allowing for quicker decision-making and a more streamlined response. It should be noted, however, that prompt initiation of investigations and control measures by the CIEVS requires a certain level of resources, especially when the event occurs at a location that is difficult to access (25). The CIEVS also maintains a direct communication channel with the countries of the Common Southern Market (Mercosur) and Union of South American Nations (Unión de Naciones Suramericanas, UNASUR), as well as the Pan American Health Organization (PAHO), to promote technical cooperation and logistical support in emergency situations in which health risks are shared across national borders.

It is no coincidence that Brazilian municipalities with small populations and those located on land borders were rated as having the poorest performance. Although they receive regular resources from the federal government to develop public health activities, they have difficulty hiring university-trained (degreed) professionals. This difficulty is minimized by the use of the computerized information network of the HSS, which allows for the receipt, in real time, of notifications of diseases and events from small towns and those in border areas at the offices of the state- or national-level HSS. With this information, state or national teams can be mobilized to implement surveillance and control measures.

The study findings indicated that most of the core capacities of the Brazilian HSS assessed in the year 2007 had met the requirements established by the IHR 2005. Practical evidence of this was the way the country managed the yellow fever event in 2008-2009. Use of the decision tool algorithm from Annex 2 of the IHR 2005 categorized this event as a potential PHE (26). Immediately after notification of the first cases in Brazil's Central-West region, in January 2008, active surveillance was established to detect epizootics in primates, which allowed for anticipatory vaccination of human populations in risky areas before the occurrence of human cases. Moreover, timely notification and investigation of human cases were carried out, alerts on areas at risk were established, the population was informed, and almost 10 million doses of vaccine against yellow fever were disseminated $(26,27)$. These measures, which helped contain the event, were the result of cooperation among health surveillance units from several states and municipalities. The reduction in the incidence of several infectious diseases, and the control or elimination of vaccine-preventable diseases as well as vector-borne Chagas disease, among other advancements, are complementary evidence that the HSS in Brazil has been effective, producing epidemiological impact and improving the population health (7).

Brazil's SUS is the result of national efforts to build a comprehensive, accessible, and equitable health system. The results obtained in this assessment indicate that these goals have been obtained with regard to Brazil's HSS, which falls under the SUS umbrella $(7,8,28)$.

\section{Limitations}

This evaluation had several limitations, including the subjective nature of the information obtained from the survey respondents, who may not have provided an accurate representation of the status of the HSS. In addition, the cross-sectional design of the study precluded analysis of the development process of Brazil's HSS. On the other hand, because the sample included key informants at all three levels of government (municipal, state, and national) from municipalities with different population sizes and different levels of economic and social development, the results can be considered quite representative of the actual status of the HSS at the time of the study.

\section{Recommended research}

Although the public health professionals interviewed in this evaluation did not mention the need for additional financial resources to expand HSS activities, the 
current level of investment does not appear to be sufficient. The survey respondents may have been unaware of the difficulties faced by top-level HSS management in supplying what is needed to carry out both emergency and routine activities. Therefore, a more detailed analysis of this issue is recommended.

\section{Conclusions}

The IHR 2005 represents great progress in the protection of public health within the context of a contemporary world in which both complex and common health problems generated by globalization must be confronted firmly and ethi-

1. World Health Organization. International Health Regulations (1969). 3rd annotated ed. Geneva: WHO; 1983.

2. World Health Assembly. Resolutions: revision of the International Health Regulations (WHA58.3). Geneva: WHA; 2005. Available from: http://www.who.int/gb/ebwha/pdf files/WHA58-REC1/english/Resolutions. pdf Accessed 28 April 2009.

3. Baker MG, Fidler DP. Global public health surveillance under new International Health Regulations. Emerg Infect Dis. 2006;12(7):1058-65.

4. Fidler DP, Gostin LO. The new International Health Regulations: an historic development for international law and public health. J Law Med Ethics. 2006;34(1):85-94.

5. Katz RL, Fernandez JA, McNabb SJ. Disease surveillance, capacity building and implementation of the International Health Regulations (IHR[2005]). BMC Public Health. 2010; 10(Suppl 1):S1.

6. World Health Organization. Strengthening national capacities for epidemic preparedness and response in support to national implementation of IHR(2005). Report of a WHO meeting. Geneva: WHO; 2006. (WHO/CDS/ EPR/LYO/2006.4).

7. Barreto ML, Teixeira MG, Bastos FI, Ximenes RA, Barata RB, Rodrigues LC. Successes and failures in the control of infectious diseases in Brazil: social and environmental context, policies, interventions, and research needs. Lancet. 2011;377(9780):1877-89.

8. Paim JS, Travassos, CMR, Almeida C, Bahia L, Macinko J. The Brazilian health system: history, advances, and challenges. Lancet. 2011; 377(9779):1778-97.

9. Ministério da Saúde (BR). Lei n 8080 de 19 de setembro de 1990. Brasilia: MS; c2000. Available from: http://www6.senado.gov.br/ legislacao /ListaPublicacoes.action?id=134238 Accessed 30 April 2010.

10. Cornwall A, Shankland A. Engaging citizens: lessons from building Brazil's national health system. Soc Sci Med. 2008;66(10):2173-84.

11. Ministério da Saúde (BR). Centro de Informações Estratégicas em Vigilância em SaúdeCIEVS [Internet]. Brasília: MS; c2010. Available from: http://portal.saude.gov.br/portal/ cally, without infringing on human rights or national sovereignty. The IHR 2005 has helped to protect human health by encouraging nations to improve their surveillance and response systems yet minimizing barriers to commerce and tourism, important activities for the economic and social development of any nation. The results of this study reflect this broad view of the IHR 2005 as well as the commitment of Brazilian health authorities and thousands of dedicated public health professionals to strengthen HSS capacity at the national, state, and municipal level. In general, the core capacities of Brazil's HSS are well established and fulfill most of the requisites listed in the IHR 2005

\section{REFERENCES}

saude/gestor/visualizar_texto.cfm?idtxt= 22233 Accessed 30 April 2010.

12. Pires MCC, Oliveira-Neto JCC. Indicador $\mathrm{Mu}$ nicipal de Saúde: uma análise dos sistemas municipais de saúde brasileiros. Brasília: Instituto de Pesquisa Econômica Aplicada; 2006.

13. World Health Organization. IHR monitoring framework: checklist and indicators for monitoring progress in the development of IHR core capacities in States Parties. Geneva: WHO; 2010. (WHO/HSE/IHR/2010.1).

14. Ministério da Saúde (BR). Sistema de Informações sobre Orçamentos Públicos em Saúde [Internet]. Brasília: MS; c2019. Available from: http://siops.datasus.gov.br/ Accessed 30 April 2009.

15. Silva-Júnior JB. Epidemiologia em serviço: uma avaliação de desempenho do Sistema Nacional de Vigilância em Saúde [dissertation]. Campinas (SP): Universidade Estadual de Campinas, Faculdade de Ciências Médicas; 2004.

16. Teixeira MG, Costa MCN. Vigilância epidemiológica: políticas, sistemas e serviços. In: Giovanella L, Escorel S, Lobato LVC, Noronha JC, Carvalho AI, editors. Políticas e sistemas de saúde no Brasil. Rio de Janeiro: Fiocruz; 2008.

17. Ministério da Saúde (BR). Portaria n 1399, de 15 de dezembro de 1999. Brasília: MS; c2010. Available from: http://www.saude.ms.gov.br/ index.php?templat $=$ vis\&site $=116 \&$ id_comp $=$ $631 \&$ id_reg $=2485 \&$ voltar $=$ lista\&site_reg= 116\&id_comp_orig=631 Accessed 12 June 2010.

18. Ministério da Saúde (BR). Portaria $n^{\circ} 184$, de 24 de junho de 2010. Brasília: MS; c2010. Available from: http://portal.saude.gov.br/ portal/arquivos/pdf/portaria_184_2010_ ms_svs_cgdant.pdf Accessed 12 June 2010.

19. Ministerio de Salud (AR). Resolucion 1715/ 2007. Buenos Aires: MS; c2006-2007. Available from: http://test.e-legis-ar.msal.gov.ar/ leisref / public/ show Act.php?id=7129\& word=Reglamento \%20sanitario\%20interna cional Accessed 26 December 2011.

20. Federal Office of Public Health (CH). Revision of the Epidemics Act. Zurich: FOPH; c2009. Available from: http://www.bag.admin.ch/ themen/medizin/03030/03209/03210/index. html?lang=en Accessed 26 December 2011. with respect to both structure and function, particularly at the national and state levels. This study also helps justify the approach of building a national plan involving all three levels of government in order to strengthen national capacity for health surveillance and response.

Acknowledgments. The authors acknowledge the managers and professionals from Brazil's national Unified Health System (Sistema Único de Saúde, SUS) who kindly agreed to participate in this study. This work was supported by the Health Surveillance Secretariat of Brazil's Ministry of Health (Secretaria de Vigilância em Saúde do Ministério da Saúde).
21. Henriques CMP. As diferentes visões filosóficas e abordagens científicas sobre a vigilância em saúde no Brasil. Rev Direito Sanit. 2009; 10(2):87-93.

22. Aith F, Dallari SG. Vigilância em saúde no Brasil: os desafios dos riscos sanitários do século XXI e a necessidade de criação de um sistema nacional de vigilância em saúde. Rev Direito Sanit. 2009;10(2):94-125.

23. Teixeira MG, Costa MCN, Viana I, Paim JS. Vigilância em saúde: é necessário uma legislação de emergência? Rev Direito Sanit. 2009; 10(2):126-44.

24. Ministério da Saúde (BR). Reportagens Especiais. Alta tecnologia na prevenção das emergências em saúde. Brasíla: MS; c2009. Available from: http://portal.saude.gov.br/ portal/aplicacoes/reportagensEspeciais/ default.cfm?pg =dspDetalhes\&id_area $=$ 124\&CO_NOTICIA=10017 Accessed 14 March 2011.

25. Carmo EH, Penna G, Oliveira WK. Emergências de saúde pública: conceito, caracterização, preparação e resposta. Estud Av. 2008; 22(64):19-32.

26. Camacho LAB. Febre amarela e saúde pública no Brasil [editorial]. Cad Saude Publica. 2008;24(3):482-3.

27. Ministério da Saúde (BR). Febre amarela silvestre, Brasil, 2009: Emergências em Saúde Pública de Importância Nacional (ESPIN) de febre amarela silvestre em São Paulo e no Rio Grande do sul e a situação epidemiológica atual no Brasil $(2008 / 2009)$ [bulletin] Available from: http://portal.saude.gov.br/ portal/arquivos/pdf/boletim_febre_ama rela_09_12_09.pdf Accessed 26 December 2011.

28. Hoffmann R, Ney MG. A recente queda da desigualdade de renda no Brasil: análise dos dados da PNAD, dos Censos Demográficos e das Contas Nacionais. Economica (Rio de Janeiro). 2008;10(1):7-39.

Manuscript received on 30 June 2011. Revised version accepted for publication on 10 January 2012. 
RESUMEN Objetivo. Evaluar el sistema de vigilancia de salud pública del Brasil, identificando sus capacidades básicas, deficiencias y limitaciones para manejar emergencias de salud pública, dentro del contexto del Reglamento Sanitario Internacional (RSI 2005).

Evaluación del sistema de vigilancia de salud pública del Brasil dentro del contexto del Reglamento Sanitario Internacional (2005)

Métodos. En el período 2008-2009 se llevó a cabo un estudio transversal de evaluación utilizando cuestionarios semiestructurados administrados a informantes clave (funcionarios del gobierno municipal, estatal y nacional) a fin de evaluar la estructura del sistema de vigilancia de salud pública del Brasil (marco jurídico y recursos), y la vigilancia y los procedimientos de respuesta, con relación al cumplimiento de los requisitos del RSI 2005 para el manejo de emergencias de salud pública de importancia nacional e internacional. Los criterios de evaluación incluyeron la capacidad de detectar, evaluar, notificar, investigar, intervenir y comunicar. Las respuestas se analizaron por separado según el nivel gubernamental (departamentos de salud municipales y estatales y ministerio de salud nacional).

Resultados. En general, en los tres niveles del gobierno, el sistema de vigilancia de salud pública del Brasil tiene un marco jurídico bien establecido (incluidas las reglamentaciones técnicas esenciales) y la infraestructura, los suministros los materiales y los mecanismos requeridos para el enlace y la coordinación. Sin embargo, todavía hay algunos puntos débiles a nivel estatal, especialmente en las zonas fronterizas y los pueblos pequeños. Los profesionales de campo deben conocer más la herramienta de decisión del anexo 2 del RSI 2005 (diseñada para aumentar la sensibilidad y la consistencia del proceso de notificación). En el nivel estatal y municipal, la capacidad para detectar, evaluar y notificar es mejor que la capacidad para investigar, intervenir y comunicar. Las actividades de vigilancia se llevan a cabo 24 horas al día, 7 días a la semana, en 40,7\% de los estados y 35,5\% de los municipios. Existen deficiencias en las actividades de organización y los métodos, y en el proceso de contratación y capacitación del personal. Conclusiones. En general, las capacidades básicas del sistema de vigilancia de salud pública del Brasil están bien establecidas y cumplen la mayoría de los requisitos enumerados en el RSI 2005, tanto con respecto a la estructura como a la vigilancia y los procedimientos de respuesta, en particular en los niveles nacional y estatal.

Palabras clave Reglamento sanitario internacional; sistema de vigilancia sanitaria; evaluación; Brasil. 